\title{
Mindfulness - en religionssociologisk analyse af et moderne fænomen
}

\author{
RIKKE GOTTFREDSEN
}

\begin{abstract}
ENGLISH ABSTRACT: Mindfulness is a phenomenon increasingly attracting interest in Denmark. It is offered by many different types of providers. This research categorizes in a complete sample of mindfulness providers in Aarhus the way in which these providers communicate their affiliation with mindfulness as respectively Buddhism, spirituality or a-religious technique. This is done using the criteria's authorization, text reference and visual reference. The article's research shows that mindfulness is offered as a-religious technique, but claims simultaneously, based on Hornborg and Durkheim, that even this alleged a-religiosity can be considered religious.
\end{abstract}

DANSK RESUMÉ: Mindfulness er et fænomen i vækst. Den udbydes af mange forskellige typer af udbydere. Denne undersøgelse kategoriserer $i$ et komplet sample af mindfulness-udbydere i Aarhus måden hvorpå disse udbydere kommunikerer deres tilhørsforhold til mindfulness som henholdsvis buddhisme, spiritualitet eller a-religiøs teknik. Dette gøres ved hjelp af kriterier inden for autorisation, tekst- og visuelle referencer. Artiklens undersøgelse viser, at mindfulness udbydes som a-religiøs teknik, men hævder samtidigt med udgangspunkt $i$ Hornborg og Durkheim, at selv denne påståede a-religiøsitet kan kaldes religiøs.

KEYWORDS: Mindfulness; Buddhism; spirituality; a-religious; Hornborg; Durkheim

\section{Kategorisering af mindfulness}

Tænker du på noget andet, mens du taler med nogen? Planlægger du, hvad du skal bagefter, mens du ser film? Kæmper du videre, når du er stresset, $i$ stedet for at holde pause? Beslutter du på forhånd, hvor længe et besøg hos familie eller venner skal vare? Bliver du let irriteret, når du holder i en bilkø? 
Er der flest 'ja'-svar, så er mindfulness noget for dig. I hvert fald, hvis du tager mindfulness-testen på hjemmesiden for Danmarks største livsstilsmagasin, I Form (2012). Interessen for mindfulness er i stadig vækst, og da baggrunden for mindfulness er buddhistisk, spørges der ofte, om mindfulness er en religion. Hertil svares 'nej, mindfulness er ikke en religion, men en teknik og en metode' fra såvel mindfulnessforfattere (Barfred 2011) som metodens grundlægger, Jon Kabat-Zinn (Szalavitz 2012). Men er det nu også så enkelt at afvise, at mindfulness faktisk er en religion? Kan mindfulness faktisk være samtidens svar på, hvad en religion skal være, for at det moderne, sekulære og ellers a-religiøse menneske opsøger en sådan?

Sociolog Katarina Plank peger i sin ph.d.-afhandling Insikt och Närvaro - akademiska kontemplationer kring buddhism, meditation och mindfulness fra 2011 på, at der er to retninger inden for mindfulness i dag, nemlig den religiøse/buddhistiske og den sekulære/terapeutiske/medicinske. Her konkluderer hun, at de to typer mindfulness adskiller sig fra hinanden på væsentlige punkter (Plank 2011, 227). Nærværende artikel tager udgangspunkt i Planks konklusion og undersøger med en kategorisering af et komplet sample af mindfulness-udbud i Aarhus, hvordan den empiriske virkelighed kan afspejle denne påstand. For er mindfulness en type buddhisme, er det spiritualitet eller er det en a-religiøs teknik? ${ }^{1}$

\section{Dobbelt anvendelse af Durkheim}

Det teoretiske udgangspunkt for undersøgelsen er en dobbelt anvendelse af Durkheims religionsdefinition, nemlig dels operativt til en definition af kategorierne, der differentierer undersøgelsens objekt, dels teoretisk til en perspektivering, der samler undersøgelsens objekt. Således er Durkheims kendte religionsdefintion en grundlæggende præmis for denne artikel:

A religion is a unified system of beliefs and practices relative to sacred things, that is to say, things set apart and surrounded by prohibitions - beliefs and practices that unite its adherents in a single moral community called a church (Durkheim 2001, 46).

For at denne teoretiske del af artiklen ikke skal blive for omfattende, vil jeg fokusere på at skildre, hvorledes mindfulness kan relateres til denne definition. Det vil give mulighed for at besvare en del af artiklens problem, nemlig hvad mindfulness egentligt er, og om det, mindfulness så faktisk er, også kan kaldes en religion. Derfor vil jeg undersøge mindfulness og de konstituerende omstændigheder, som mindfulness relaterer til ved, hjælp af definitionens fire kernepunkter:

Undersøgelsen og analysen er i øvrigt foretaget og yderligere argumenteret for i min specialeafhandling 'mindfulness - en religionssociologisk analyse af et moderne fænomen' (2012). 
1. Et helstøbt system af trosforestillinger og praksisser (a unified system of beliefs and practices)

2. Hellige ting (relative to sacred things)

3. Forbud (set apart and surrounded by prohibitions)

4. Moralsk fællesskab (beliefs and practices that unite its adherents in a single moral community called a church)

Det er vigtigt at bemærke at 'hellige ting' ikke skal isoleres til guder eller hellige ting, men også inkluderer fx buddhismens helligholdelse af de fire ædle sandheder og de praksisser, der stammer derfra. Dette hævder Durkheim er afgørende for, at buddhismen er en religion (ibid., 37). At det dog ikke er en helt enkel distinktion, ses af fx Herbrechtsmeiers diskussion af filosofi- og religionsdefinitioner (Herbrechtsmeier 1993); men for nærværende argument er Durkheims definition den gældende.

\section{Kategorierne}

At kategorisere og sammenligne er en konstruktiv og ordnende, men også forsimplende og generaliserende metode til undersøgelse af et felt. Men fordelene ved kategoriseringen må her opveje ulemperne, og andre har da også tidligere foretaget forskellige kategoriseringer af mindfulness ud fra relevante perspektiver. Plank skelner i sin afhandling - det er buddhisme i Sverige, der er hovedobjektet for hendes undersøgelse - mellem religion og ikke-religion, som hun inddeler i henholdsvis klinisk anvendelse af mindfulness (MBCT og DBT) og 'Life Skill'-forbedrende mindfulness (Mindfulness Based Stress Reduction (MBSR)). I Barfreds kandidatspeciale sammenlignes mindfulness, buddhisme og New Age, og hun finder mange lighedspunkter. På den baggrund kategoriserer Barfred mindfulness i tre typer: en New Agerelateret, en sekulær/let spirituel (svarende til Planks 'Life Skill') og en kognitionspsykologisk type, målrettet behandlingssammenhænge (svarende til 'klinisk'). Jeg understøtter med denne undersøgelse disse tre kategoriseringer, men ønsker at tilføje en religionsundersøgende præmis.

Spørgsmålet, hvorvidt mindfulness er religion, stilles nemlig både af Plank og Barfred. Barfred konkluderer på baggrund af iagttagelser inden for mindfulness og mindfulness-forfatteres selvforståelse, at mindfulness ikke er en religion, men at den kan anvendes 'i relation til New Age tro og praksis, da der (...) er adskillige af de grundlæggende antagelser inden for mindfulness, som harmonerer med New Age tankegang' (Barfred 2011, 30). Plank åbner for en bred forståelse af religionsbegrebet med professor i religionshistorie Anne-Chritine Hornborgs analyse af 'sundhedsreligion', som jeg anvender som udgangspunkt for en af kategorierne i denne undersøgelse. Således er min undersøgelse altså ikke en kritik af Plank og Barfred, men kan ses som en uddybende tilføjelse til deres analyser. 


\section{Den buddhistiske kategori}

Mindfulness er inspireret af buddhisme, og derfor ses buddhisme udtrykt på forskellig måde i alle undersøgelsens tre kategorier. Vestens mest direkte adaption af buddhisme sås i udbredelsen af Theravada- og Mahayana buddhisme i årene efter Anden Verdenskrig, hvor krigens grusomheder og ødelæggende konsekvenser fik mange til at søge ikke-kristne alternativer. Fra 1950'erne kom Vipassana og interessen for Zen-meditation til (Lopez 2008, 30-31), og det er dette spor, der danner baggrund for undersøgelsens buddhistiske kategori.

Med baggrund i Durkheims religionsdefinition kan buddhismen skildres som et helstøbt system af trosforestillinger og praksisser - et system, fordi systematik nærmest er en signatur for buddhismen. Både i den direkte betydning, hvor fx lotusblomstens opbygning og de dogmatiske strukturers nummereringer gør Buddhas anvisninger lettere at huske, og i en bagvedliggende betydning, nemlig i den måde, etik, filosofi og dogmatik fremstilles på. Buddhismens hellige ting er, som allerede nævnt, ikke selve Buddha, men Buddhas lære. Derfor kan det synes modsætningsfyldt, at buddhismens symbolverden er tætpakket af 'ting' med hellige betydninger: bedemøller, flag og vimpler, røgelse, dekorationer, templer, altre og Buddha-figurer. Men disse skal forstås som hukommelsesfremmende artefakter, der støtter op om buddhismens rette tanker og handlinger. Forbud ses i buddhismen ikke i imperativ-form, som i fx kristendommen, men som anvisninger, der kan lede på rette vej. Fx kan det at have rette intentioner føre i retning mod udfrielsen (Nirvana), hvor dårlige intentioner leder væk fra den. Det moralske fællesskab, Durkheim refererer til som 'kirke' (Durkheim 2001, 42), ses i buddhismen, som Durkheim også beskriver det, i flere former. Det religiøse samfund (sangha) inkluderer både den radikale form for samfund omkring de munke- og nonneklostre, hvor enkeltpersoner trækker sig tilbage fra det almindelige liv, og den ordinære form, som tæller hele det buddhistiske fællesskab i et almindeligt hverdagsliv.

Konkluderende kan det derfor bekræftes, at buddhismen ud fra ovenstående kriterier er en religion, der har et helstøbt system af trosforestillinger og praksisser, nemlig Buddhas lære om dharma udtrykt. Den relaterer til hellige ting, som er hukommelsesfremmende artefakter, der peger på Buddhas lære, som er omkranset af anvisninger af rette intentioner og afholdenhed. Buddhismen forener medlemmerne $\mathrm{i}$ et moralsk fællesskab, hvor alle slutter op om Buddhas lære og anvisninger.

\section{Den spirituelle kategori}

Den spirituelle kategori har baggrund i et andet buddhistisk spor end den buddhistiske kategori. Fra slutningen af 1800-tallet blev videnskabens fremmarch med fx Darwins teori om naturlig selektion forsøgt modstået som en oprustning af den eksisterende, traditionelle religion. Her tog fx Teosofisk Selskab buddhismens holistiske tanker til 
sig og proklamerede opdagelsen af et ældgammelt og esoterisk system, en spirituel evolution, som skulle være mere vidtrækkende og dybsindig, end noget Darwin havde beskrevet (Lopez 2008, 10). Denne tilgang bliver konstituerende for de nye religiøse bevægelser, der i sidste tredjedel af det 20. århundrede tager buddhismen til sig.

Med udgangspunkt i en universel forestilling om, at al spiritualitet har samme udgangspunkt, at den er vedvarende og tro mod helheden i naturens orden, og at det guddommelige er at finde i enhver, ser spiritualitetsbevægelsen med mistænksomhed på traditionel tro. 'I trust my inner wisdom', som Louise L. Hay udtrykker det (www.louisehay.com), og den enkeltes søgen efter spiritualitet bliver en søgen efter det guddommelige i selvet. Som guide for den indre søgen afviser spiritualitetsbevægelsen deciderede helligtekster og kanoniserede skrifter; men her findes et stadigt voksende korpus af filosofiske værker, selvhjælpsbøger og visdomsord. En del af dem er inspirerede af østens filosofi, mystik og religion, så Buddha, Gandhi (Woodhead 2000, 112), og Dalai Lama citeres ofte sammen med Eckhart Tolle, Hay og Kabat-Zinn. Derfor er det heller ikke ligetil at konkludere, at spiritualitet faktisk er et helstøbt system af trosforestillinger og praksisser, for det helstøbte er her mere flydende, end det ses inden for fx buddhisme-kategorien. At der fx ingen centrale autoriteter findes inden for spiritualitet, hvor al aktivitet foregår via netværker fra kurser, workshops og webinarier, kan umiddelbart tyde på et sammenfald med Baumans 'æstetiske fællesskaber' uden faste forpligtelser eller langsigtede engagementer (Bauman 2001). Men kun umiddelbart. For spiritualitetsbevægelsen indvarsler med 'New Age' både selvrealisering og forandring af hele samfundet: Det er manifestationen af spirituel stræben, der skal bringe kærlighed, visdom og lys (forstået som i 'oplysning' eller 'forklarelse') til den enkelte og via den enkeltes nye bevidsthed påvirke hele universet (Bloom i Perry 1992, 33-35). Tilsammen udgør disse overbevisninger et helstøbt system af trosforestillinger og praksisser.

Det er det subjektive udgangs- og endepunkt, der i harmoni med det guddommelige afgrænser spiritualitet fra både den religionsbaserede buddhisme og fra den areligiøse teknik. De hellige ting, som Durkheim anfører religioner har en relation til, består inden for spiritualitet af helligholdelsen af en spirituel og fundamental overensstemmelse mellem det guddommelige i menneske og natur: "The outer personality is limited and tends towards materialism. The inner being is infinite and tends towards love" (ibid.). Der er ingen direkte forbud eller begrænsninger forbundet med spiritualitetsbevægelsen; men der ligger implicitte og allestedsnærværende muligheder for at forbryde sig mod den altomfattende helhed og energi. At drage spirituel og praktisk omsorg for menneskeheden, kloden og universet er således grundmoralen for de spirituelle frllesskaber.

Således kan jeg konkludere, at også spiritualitet, relateret til Durkheims religionsdefinition, er en religion, der har et helstøbt system af trosforestillinger og praksisser. Disse skal dog her forstås i lyset af den flydende modernitet, og derfor kan systemet 
og praksisserne ikke defineres på baggrund af fx enkelte helligtekster, men er en kompleks størrelse, der har helligholdelsen af en spirituel og fundamental overensstemmelse mellem det guddommelige i menneske og natur som kerne. Forbud ses som vejledninger $i$, hvorledes man undgår at forstyrre universets harmoni, og det er enigheden om disse overbevisninger, der former de moralske fællesskaber. Fællesskaberne er ligesom trossystemet flydende og ses i højere grad som åbne netværk end som lukkede grupper.

\section{Den a-religiøse kategori}

Et tredje spor, der har udgangspunkt i buddhismen kommer fx til udtryk med et citat af Guruge fra 1965: "Higher Buddhism is pure science. It has no place for theology" (Guruge i Borup 2006, 658-59). Baggrunden for et sådant udsagn skal ligesom i den spirituelle kategori ses i sidste halvdel af 1800-tallet, men for den a-religiøse kategori dog findes blandt de mindst klerikale, victorianske forskere, for hvem buddhisme var "a tradition, that saw the universe as subject to natural laws, without the need for any form of divine intervention" (Lopez 2008, 7).

Hvor spiritualiteten kan ses som en genfortryllelse, ville det være nærliggende, at fremstille den a-religiøse kategori som affortryllet. Men så enkelt er det ikke. For baggrunden for den a-religiøse kategori er ganske vist det sekulariserede og videnskabsbaserede paradigme. Men ud af det helt affortryllede livssyn opstår en genfortryllet religion: Den er en ny og omfattende trosform, som Hornborg kalder 'Hälsens religion', altså en sundhedsreligion² (Hornborg 2010). En af grundene til dyrkelsen af sundheden ligger, ifølge Hornborg, implicit i modernitetens vilkår: Efter at være blevet pisket rundt af modernitetens elpisker, som hun udtrykker det, er mennesket landet uden tilknytning til hverken sted, mennesker eller traditioner, og de må nu finde en ny mening, hvor de tilfældigvis er havnet. Da det nye sted ikke er etableret med nye traditioner eller relationer til nye mennesker, bliver det nye sted, det eneste materielle, man har med sig overalt, nemlig kroppen. Troen på 'my inner wisdom' som Hay udtrykte det, er med Hornborgs elpisker trængt fra troen på energibaner, selvet og det guddommelige indre lys til troen på den langt mere manifeste 'krop'. Kroppen har dog stadig et indre liv (ibid., 151-52), men det er forbedringen, udfordringen, undersøgelsen og vedligeholdelsen af den fysiske krop, der bliver det enkelte individs nye omdrejningspunkt, det nye 'herfra min verden går'.

Det første kriterium i Durkheims religionsdefinition må her anskues kontraintuitivt, da det helstøbte system inden for den a-religiøse teknik ikke har fast og stationær

\footnotetext{
Jeg vælger at oversætte 'Hålsens religion' med 'sundhedsreligion' for dels at undgå det på dansk gammeldags 'helse', der ganske vist kunne være korrekt, men som kan konnoteres med 1960'ernes og 70 'ernes hippie-bevægelse, og dels det i dette tilfælde for lette 'wellness', da 'sundhedsreligion' skal dække et væsentligt bredere felt end blot 'velvære'. En alternativ benævnelse kunne være 'sundhedisme' (Hvas 2012).
} 
karakter, som 'states of opinion' (Durkheim 2001 [1912], 35-36) kunne indikere, men tværtimod en kontinuerlig forandring, der med opdatering og udvikling sikrer sundhedsreligionen som et system. Her ses, i sammenligning med 'buddhisme' og 'spiritualitet', en nærmest ekstrem iver i tilpasningen af de praksisser, der anvendes for at vedligeholde trosforestillingerne. Et eksempel på en sådan opdatering ses i Danmarks mest læste magasin for kvinder (www.tns-gallup.dk), nemlig månedsmagasinet I Form, hvis læsere ifølge magasinets præsentation af sig selv altid skal kunne føle sig sikre på at have den nyeste og mest nyttige viden (I Form 2011). Der er derfor intet problematisk i, at hvad der var gældende i går, ikke er gældende i dag.

Det helstøbte system af trosforestillinger og praksisser, som Durkheim lader være grundlaget for det moralske fællesskab, er således i sundhedsreligionen et system i konstant forandring. Systemet er funderet som en forbudsreligion, hvor det, der kommer imellem sundheden og den enkelte, bryder med det tilladte. Den utilregnelige djævel er 'skaden', hvad enten det er en løbeskade eller den selvskade, man pådrager sig ved at tage fem kilo på i julen. Sundhed er den nye helligdom, og træningsudstyret er de hellige artefakter, der giver mulighed for bedre præstationer og dermed nærmere og mere intensiv kontakt med det hellige og denne formidles ved hjælp af de rituelle praksisser: Træning og kontrol. Det moralske frllesskab samles og mødes i naturen, på kurophold og wellness-retreats og i trænings- og fitnesscentre (Hornborg 2010). Også her udveksles viden og erfaringer om de seneste nyskabelser og forskningsresultater om sundhed. Sådan kan det konkluderes, at ud fra denne lille analyse med afsæt i Durkheims religionsdefinition kan man godt kalde den ellers påståede a-religiøse teknik for en religion, nemlig, som Hornborg også kalder den, sundhedsreligion. Den repræsenterer og sammenfatter kategorien, hvor mindfulness udbydes som en a-religiøs teknik.

\section{Selve undersøgelsen}

Der er metodiske udfordringer og overvejelser forbundet med ethvert forskningsprojekt, og for min undersøgelse har den største overvejelse omhandlet de generaliseringer de ovenfor anvendte kategorier vil være udsat for i en tolkningsproces. I denne undersøgelse har jeg valgt en vekslen mellem kvalitativ og kvantitativ analyse: Først foretages en kvalitativ vurdering af udbyderens materiale for derefter at kunne kategorisere data til et kvantitativt materiale. Dette anvendes til sidst som udgangspunkt for en kvalitativ analyse, refleksion og konklusion. Generaliseringerne er nødvendige for en anvendelig grænsedragning, og i arbejdet med en sådan bliver det tydeligt, at 'djævlen bor i detaljen': Eksempelvis er det umiddelbart let at tolke en udbyders anvendelse af et foto af Buddha som en 'buddhistisk visuel reference' (www.jpsc.dk). Sværere er det at kategorisere anvendelsen af et baggrundstapet med en otte-delt blomst (www.mind-institute.dk). Det til trods er det dog min overbevisning, at nærværende sample og den efterfølgende registrering udgør et validt og 
komplet billede af udbyderne af mindfulness i Aarhus under de anførte kategorier og dimensioner inden for den angivne tidsperiode.

\section{Kriterierne}

Disse tre kategorier, buddhisme, spiritualitet og a-religiøs teknik, anvender jeg nu som ordnende for undersøgelsen af den empiriske virkelighed, nemlig hvorledes udbydere af mindfulness i Aarhus kommunikerer relationen til kategorierne via deres opslag på internettet. En kategorisering vil afsløre både forskelle og ligheder, så derfor har jeg valgt kriterierne autorisation, tekstreference og visuel reference, der hver for sig vil kunne demonstrere dette med den valgte metode. Kriterierne anvendes som markører inden for de respektive kategorier og er nærmere beskrevet i afsnittene herunder. Således er kriterierne ikke anvendt direkte som deciderede søgeord, men som kilde til min subjektive tolkning og vurdering af relationen til den ene eller anden kategori.

\section{Mindfulness i Aarhus}

Aarhus er Danmarks næststørste by med knap 310.000 indbyggere i hele kommunen og udgangspunktet for undersøgelsen er således en by, der er større end andre danske provinsbyer, men væsentligt mindre end hovedstaden. Særligt for Aarhus er, at den som universitetsby har forholdsmæssigt unge og veluddannede indbyggere sammenlignet med andre provinsbyer.

For indsamlingen af data til denne undersøgelse gælder, at det udgør et sample udvalgt ved hjælp af søgemaskinen Google.com. Det er således en meget stor mængde af data, der ligger til grund for undersøgelsen, hvilket kan være en fordel, men som også samtidig åbner muligheder for manglende præcision. Internettet er nemlig ikke 'bare' internettet: Dels er det vigtigt at være opmærksom på søgemaskinens præmis, som er en løbende opdatering af hits relateret til søgeordene foretaget fra samme IP-adresse, dels det faktum, at søgningen er foregået over en tidsperiode fra 20.7.2010 til 22.9.2011, efter hvilket tidsrum enkelte hits kan være forsvundet eller nye dukket op. Da undersøgelsens fokus er en kategorisering af mindfulness-udbud, er det nødvendigt at foretage en definition af, hvad et 'udbud' er: Her anvendes det i betydningen 'en person, der tilbyder viden om/træning i/terapi med' mindfulness.

I søgningen fremkommer der 633 hits i første søgning, men disse fokuseres af Google til 254. ${ }^{3}$ Denne fokusering er en frasortering af fx gentagne avisannoncer, artikler eller allerede viste omtaler af oplistninger af psykologer fra psykologforeningen. Efter en granskning af disse 254 opslag er det endelige sample på 83 udbydere af mindfulness i Aarhus, der opfylder kriterierne og

Efter visningen af de 254 hits vises teksten: 'For at vise dig de mest relevante resultater, har vi udeladt nogle af de resultater, der i meget høj grad ligner de 633, der allerede er vist. Hvis du vil, kan du gentage søgningen, så de resultater, der er udeladt, kommer med'. De er kort gennemgået for kontrol af rigtigheden i denne påstand, og den blev fundet i overensstemmelse med resultatet. 
1. anvender ordet 'mindfulness'

2. er udbyder

3. er udbudt inden for postnummer $8000-8270$

4. er udbudt inden for det angivne år

Da opslagene er reklamer eller omtaler af mindfulness-udbud, skal man ikke her forvente hverken en akademisk grundighed eller en kritisk tilgang til mindfulness af dem. Men her skal heller ikke forventes en ekstrem anprisning af fænomenet, da udbyderen formentligt ikke vil fremstå utroværdig. Undersøgelsessamplet er altså kommercielle udbydere af mindfulness, der, uanset om udbuddet gælder klinisk anvendelse eller forbedring af 'Life Skill' (Plank 2011, 219), har en vare at sælge.

\section{Undersøgelsens resultater}

Antal: Der er på baggrund af den valgte metode 83 udbud af mindfulness i Aarhus i perioden på ca. et år. Med reference til de ovenfor beskrevne buddhistiske, spirituelle, og a-religiøse kategorier er de fordelt således:

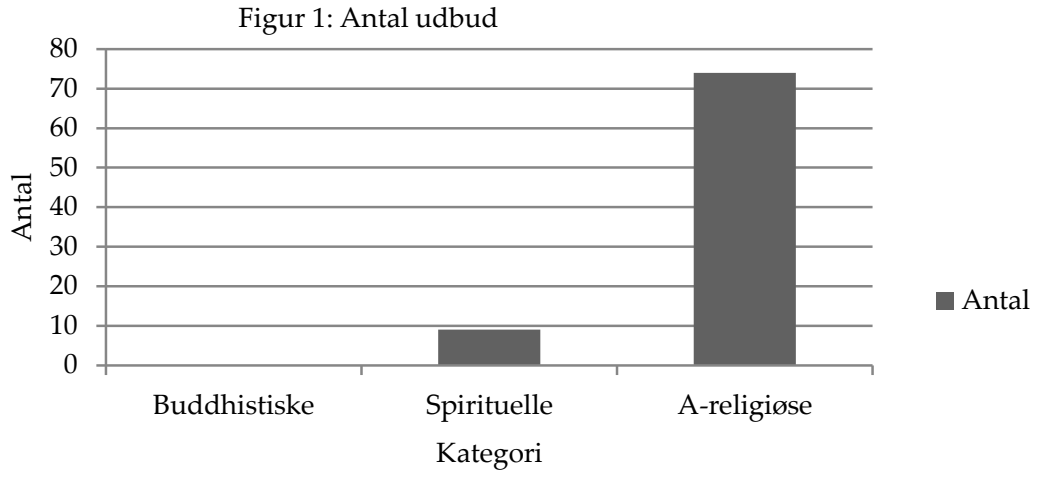

Der er altså ni mindfulness-udbydere i den spirituelle og 74 udbydere i den a-religiøse kategori. Der fremkommer med denne kategorisering, muligvis overraskende, ingen udbydere af mindfulness i den buddhistiske kategori. Man kunne ellers have troet, at en af de fire buddhistiske foreninger, 'Øsal Ling - Tibetansk buddhistisk center i Aarhus', 'Rangjung Yeshe', ‘Århus Zendo' og 'Karma Kadjy Skolen' (Center for Samtidsreligion 2011b), havde optrådt i søgningen; men da ingen af dem anvender ordet 'mindfulness' på deres hjemmesider, er disse fire ikke en del af samplet.

Der kan fra disse buddhistiske foreningers side være en helt bevidst afgrænsning til 'mindfulness', og forklaringen kan ligge implicit i netop ordet 'udbud'. Det er rimeligt at forestille sig, at buddhisterne lægger afstand til 'mindfulness', som det $a$ religiøse terapi-tilbud mindfulness udbydes som. Som Plank sammenfatter det, er der nemlig, set fra et buddhistisk synspunkt, en risiko for, at den mindfulness, der inden 
for den buddhistiske tradition gives gratis som gave fra lærer til elev, udvandes ved den kommercielle effektivisering og standardisering, der foregår ved holdundervisning og faste kursusforløb (Plank 2011, 221).

I Aarhus er der altså 83 udbydere af mindfulness; ingen af dem er buddhistiske, nogle få er spirituelle og den overvejende del er a-religiøse.

Autorisation: I denne undersøgelses sample er objekterne de opslag, der er forfattet med det formål at tilbyde forbrugeren en vare. Varen er her mindfulness i en eller anden form. Da markedet for mindfulness eller lignende tilbud ikke er centralt reguleret eller kontrolleret, er det væsentligt for den enkelte udbyder at opbygge et tillidsforhold til forbrugeren på ganske kort tid. Tilliden skal kunne opbygges helt forfra, altså uden sikkerhed for at forbrugeren har fået tilbuddet anbefalet af andre eller kan hente sikkerhed for dets kvalitet via fx en brancheforening eller lignende. Skal man appellere til at blive opfattet som troværdig og tillidsvækkende, er anvendelsen af etos i en kommunikation et kernepunkt. Denne etos, eller image, opbygges med forskellige virkemidler, og her er den autoritet, man henviser til, en af de tungtvejende. Inden for buddhismen angives autoritet oftest med en lineær pegen tilbage i tid, der henviser til den eller de mestre, man har lært af (Lopez 2008, 14). Således foregår det i princippet også inden for videnskaben, hvor det dog er universitetsgrader, titler og karakterer, der afslører, hvorledes man er uddannet, og med hvilken autoritet man fremstår. Derfor er der en væsentlig pointe i at anføre eventuelle autorisationer i præsentationen af afsenderen eller afsenderne af mindfulness-udbuddet.

Min hypotese er, at der endvidere vil kunne findes forskellige typer autorisationsangivelser inden for hver kategori. Derfor undersøges følgende kriterier:

Buddhisme: Her forventes reference til læremester, buddhistiske kurser, retræter eller længerevarende ophold på klostre, angivelse af lærers eller egen buddhistiske titel som fx Bhiksu/Gelong (munk), Bhiksuni/Ani (nonne), Lama, Rinpoche.

Spiritualitet: Her forventes meget blandede eller slet ingen referencer, da det ikke er autorisationen, men 'kontakten' med 'selvet', der er legitimerende.

A-religiøs teknik: Her forventes angivelser af videnskabelige universitetsuddannelser, længerevarende uddannelser og certificerede kurser. 
Figur 2: Autorisation

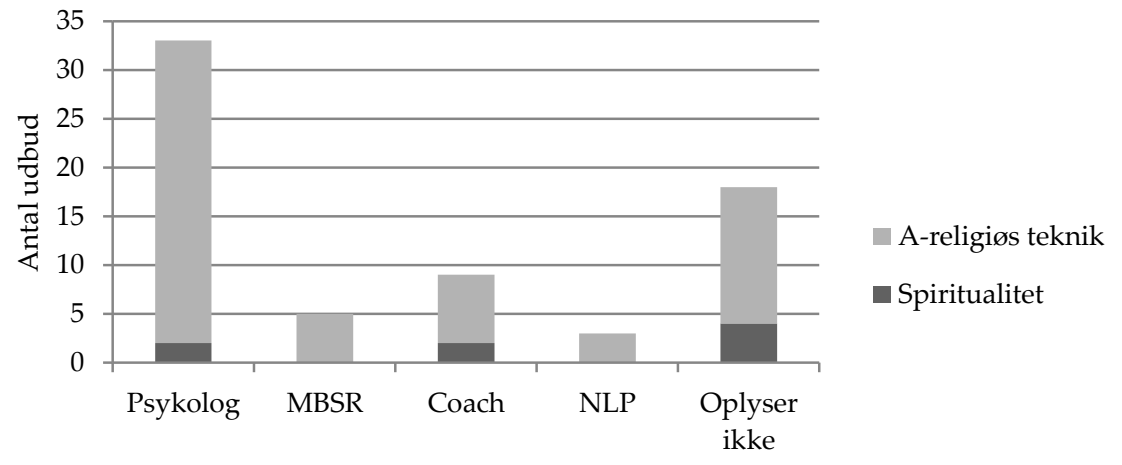

Autorisation

At angive en form for autorisation imødekommer 65 af de 83 udbud. Den oftest forekommende autorisation i undersøgelsen er 'psykolog' eller 'psykiater', som er angivet af 33 udbydere. Knap 40 \% har altså denne længere videregående og videnskabeligt funderede uddannelse inden for feltet.

Derudover nævnes forskellige typer 'coach' syv gange og 'NLP-practitioner' tre gange i alt. Dertil kommer sygeplejersker, fysioterapeuter, pædagoger, psykoterapeuter, afspændingspædagoger, en BA i kinesisk medicin, en lærer i Alexanderteknik og et par cand.mag.'er i filosofi som uddannelsesmæssig baggrund for mindfulness-udbuddet. Ingen har angivet uddannelser helt uden for feltet. 18 udbydere nævner ikke nogen form for autorisation, hvilket i sig selv kunne angive en tilknytning til den spirituelle kategori. Jeg har dog kun med belæg i de øvrige kriterier kategoriseret fire af dem til at være spirituelle. Som det ses af ovenstående figur 2, er andelen af psykologer størst blandt de a-religiøse, hvor andelen af mindfulness-udbydere, der ikke angiver uddannelsesmæssig baggrund, er forholdsmæssig stor i den spirituelle kategori.

I mindfulness-sammenhænge, som er denne undersøgelses fokus, er det antageligvis MBSR-certificeringen fra CFM (Center for Mindfulness ved University of Massachusetts), ${ }^{4}$ der vejer tungest. Den er der fem af udbuddene, der angiver som autorisation. Af de fem udbud forestås to af den samme mindfulness-instruktør. MBSRcertificeringen findes i samplet kun i den a-religiøse kategori, og det kan være et tegn på, at udbydere i den a-religiøse kategori lægger afstand til den spirituelle kategori. Hvor de spirituelle bygger på egen erfaring af det hellige i personen selv og kurser af kortere varighed, bygger de a-religiøse på en længere og videnskabelig funderet uddannelse. Denne skelnen er måske også grunden til, at mindfulness-udbydere kun i meget ringe grad deltager i fx en alternativ messe som 'Krop-sind-ånd'-helsemessen,

Uddannelsen til professionel instruktør eller underviser i MBSR varetages af 'Oasis Institute for Mindfulness-Based Professional Training and Education' under CFM (www.umassmed.edu/cfm/ oasis.index.aspx). 
der fandt sted i Aarhus d. 28.-30.9.2011. For ud af 126 udstillere var der kun tre, der i udstillermaterialet anvendte ordet 'mindfulness', og heraf var kun en enkelt genganger, www.moeberg.dk, fra det i denne undersøgelse anvendte sample (Krop-sindånd Helsemesse 2011).

Det kan således kort opsummeres, at den overvejende del af mindfulnessudbyderne angiver en autorisation, og af dem er halvdelen psykologer. En femtedel af udbyderne angiver ingen form for autorisation eller uddannelse som baggrund for deres udbud.

\section{Tekstreference}

Med en analyse af den egentlige tekst, der anvendes i et dokument, er der oftest tale om en hermeneutisk tilgang, medmindre man foretager mere strukturelle analyser. I denne undersøgelse er et eksempel på en sådan tilgang den lille analyse af materialet fra 'krop-sind-ånd'-messen herover, hvor det er forekomsten af særlige ord, der tælles og derved tillægges betydning. Også hele undersøgelsens empiri er baseret på forekomsten af ordet 'mindfulness'. Men for den følgende del af undersøgelsen gælder altså en bredere og hermeneutisk ramme. Det er således dokumentets tekstuelle mening og intention, der forsøges tolket, vurderet og kategoriseret. Her vil være mulighed for problematiseringer, diskussioner og andre tolkninger, der kunne influere på en forskydning mellem kategorierne; men med belæg i de anvendte dimensioner er det min vurdering, at en sådan mulig forskydning ikke i det væsentlige vil forandre den endelige konklusion.

I mindfulness-udbydernes tekster undersøger jeg følgende kriterier:

Buddhisme: Her forventes direkte referencer til buddhismen i alle grader fra det overordnede formål til legitimerende referencer, fra Buddha-citater til benævnelsen af. at mindfulness relaterer til buddhismen.

Spiritualitet: Her forventes referencer til åndelighed, indre spiritualitet, indre lys, universelle kræfter, energier og energibaner samt en styrkelse af 'det indre' og 'selvet.'

A-religiøs teknik: Her forventes videnskabelige forskningsbaserede referencer samt referencer til effektivitet, fysisk og psykisk forbedring, mental træning og nyeste resultater. 
Figur 3: Tekstreferencer

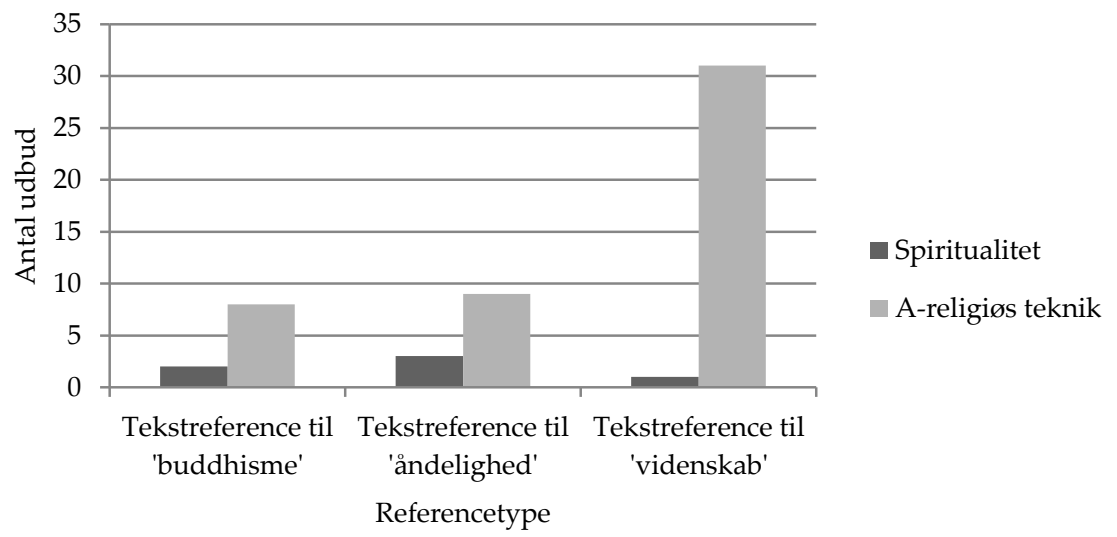

I figur 3 herover er vist, hvorledes der refereres til de tre hovedkategorier i dokumenternes tekster. For at der ikke skal opstå unødig forvirring i forhold til anvendelsen af den spirituelle kategori og 'tekstreference til spiritualitet', anvendes 'åndelighed' i stedet om tekstreferencen. Det er et ofte anvendt begreb i dokumenterne, der derfor kan anvendes som markør. Således gælder det også for den a-religiøse kategori og 'tekstreferencen til videnskab'. I alt er der fundet eksplicitte tekstreferencer til kategorierne i 55 af dokumenterne.

En tekstreference til buddhisme ses i disse eksempler; 'Ved at følge programmet, som ofte kaldes 'de fem tibetanere'" (www.mind-and-motion.dk) eller 'Mindfulness har rødder tilbage i den buddhistiske tradition, nærmere bestemt Vipassana, som er en universel buddhistisk meditationsteknik' (www.sensitiveksistens.dk). Her anvendes buddhistiske begreber på samme måde som de ville kunne anvendes inden for buddhistisk praksis.

Referencer til åndelighed ses fx i udbuddet hvor ‘[d]er vil være mange øvelser til at se/forstå/erkende dig selv, din psyke og din spiritualitet' (www.uniheal.dk), og hvor en udbyder underviser i at 'fokusere på nærvær, hengivelse og personlig udvikling i denne livsfase. Sikkerhed og ånd går hånd i hånd' (www.ambika.dk). At søge selvudvikling og bruge tid på fordybelse i egen åndelighed er karakteristiske træk for spiritualitet-kategorien.

De videnskabelige tekstreferencer er de oftest forekommende i dokumenterne. En psykolog skriver at hun 'anvender primært den psykodynamiske, den kognitive samt den systemiske metode og kan desuden trække på min efteruddannelse inden for Mindfulness' (www.psykologcamilla.dk) og til et fyraftensmøde i en a-kasse for højtuddannede i erhvervslivet er der 'indlæg af: Christian Gaden Jensen, psykolog og PhD-studerende, The Neuroscience Centre, Rigshospitalet' (www.ca.dk). Her anvendes fagtermer fra universitetsstudierne i psykologi, og der henvises både direkte til videnskabelige forskningsartikler og -resultater (www.kognitivgruppen.dk/læs 
mere) og et muligt forsøg på samme, men i en mere løst postuleret form: 'Alle anvendte arbejdsmetoder er solidt videnskabeligt underbyggede' (www.eladchone.dk), og 'forskning har vist at regelmæssig ...' (ww.sannehauge.dk).

Det er bemærkelsesværdigt, at forholdsvist mange refererer på tværs i kategorierne; udbydere i den a-religiøse kategori nævner også buddhisme (www. sociallaegeinstitutionen.dk) og udbyderne i den spirituelle kategori refererer også til igangværende forskning (www.findbalancen.dk/qigong), hvilket sandsynligvis skyldes den tradition for sammenvævning af videnskab og buddhisme, der er nævnt i afsnittet om 'den a-religiøse kategori'.

\section{Visuel reference}

Ligesom det er relevant at betragte, fortolke og analysere en tekst, er det relevant at anvende disse platforme for en undersøgelse af den kontekst, teksten optræder i. Først i dette afsnit redegjorde jeg for den måde, samplet var fundet på via internettet; her skal nu ses nærmere på det enkelte samples visuelle udtryk, når det klikkes frem på skærmen. Da formålet er en vurdering i forhold til artiklens problem, nemlig hvorvidt mindfulness er en type buddhisme, spiritualitet eller a-religiøs teknik, er den følgende analyse ikke en tilbundsgående visuel-retorisk analyse, men en analyse af mindfulness-udbyderens umiddelbare anvendelse af billeder. En tekst, der er ledsaget af et eller flere billeder, har nemlig flere typer af meddelelser til tekstens modtager end tekster, der ikke har, hvilket ses eksemplificeret senere i analysen. I analysen af dokumenterne medgår farveanvendelsen som markør sammen med de øvrige markører som autorisation, tekst- og billedreference. Udover anvendelsen af farver er der nemlig også den mere direkte kommunikation ved hjælp af billeder, der forestiller noget specifikt og som dermed repræsenterer en mere enkel meddelelse end fx anvendelsen af farver ${ }^{5}$.

I mindfulness-udbydernes anvendelse af visuelle virkemidler vil jeg derfor undersøge, om nogle af følgende kriterier skulle være opfyldt:

Buddhisme: Her forventes billeder af lotusblomster, yogastillinger, templer, munke, nonner, farven orange og Buddha og artefakter som $\mathrm{fx}$ bedeklokker.

Spiritualitet: Her forventes naturfotos med roligt vand, hav, himmel, planter, træer, græs, marker. Her kunne også være grafik, der illustrerer 'at gå mod lys' eller 'at udstråle indre lys'.

A-religiøs teknik: Her forventes tekst uden billeder, mennesker i interaktion, huse, kort, illustrationer, der symboliserer 'overskud' eller 'vitalitet' som friske æbler, pænt

En mere omfattende visuel analyse kunne ligesom farveanvendelse indeholde art og teknik, komposition, tekstur, valør, lys og skygge, stil, men er ikke relevant for denne artikels problem (Kjeldsen 2006). 
ført kalender med 'god tid', løbesko eller træningsredskaber som yogamåtte, pilatesbold e.l.

Figur 4: Visuelle referencer

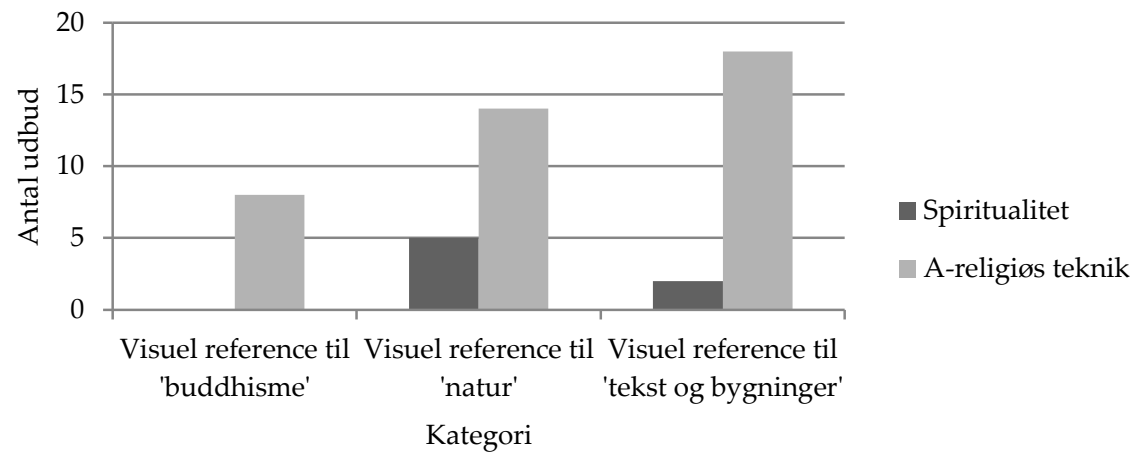

I dokumenterne findes otte visuelle referencer til 'buddhisme'. Det er fx et foto af en Buddha-statues ansigt anvendt som link-illustration til kurser i mindfulness (www.jpsc.dk) eller et foto af en mediterende person med fingrene placeret i jnana mudra $^{6}$ (www.fysio.dk). Naturen er et andet - og det største - tema blandt de visuelle referencer. 19 dokumenter anvender sådanne naturbilleder, der ofte afbilleder store vidder med åbent, roligt hav og bjerge (fx www.moksha.nu, www. lifeinmotion.dk og www.klausbertel.dk). Også udsnit af naturen, hvor man som modtager er 'tættere på' eller 'inde i', ses ofte (fx www.integrativgestalt.dk, www.mindfulnessogkrop.dk og www.healthgroup.dk). Den næststørste gruppe inden for visuelle referencer er helt uden billeder. For 15 dokumenters vedkommende er der udelukkende tale om anvendelse af tekst, hvor overskrifter, logoer o.l. har en grafisk udformning, der adskiller sig fra den almindelige brødtekst ( $\mathrm{fx}$ www.spine.dk, www.psykolog-i-aarhus.com og www.sensitiveksistens.dk). Sammen med dem lægges de fem dokumenter, der anvender billeder af bygningen eller interiøret hvor kurset eller terapien foregår ( $f x$ www.psykologerneistudsgade.dk og www.livsfabrikken.dk).

Ud over de ovennævnte kategorier ses også en gruppe på ti dokumenter, der anvender billeder af mennesker, enten i dialog, samvær eller alene. Disse finder jeg enten dobbelttydige eller enkeltstående, og jeg medtager dem derfor ikke i figur 4 herover.

Det bemærkelsesværdige ved disse referencer er, at de alle forekommer i dokumenter i den a-religiøse kategori. De skal derfor ikke nødvendigvis ses som en direkte buddhistisk-religiøs reference, men nærmere som en strategisk legitimering af kendskabet til mindfulness' oprindelse.

Jnana mudra er et buddhistisk håndtegn, der udover at betyde visdom eller læring også anvendes effektiviserende under meditation (Harvey 1990, 266). 
Denne anvendelse kan tolkes som ønsket om samhørighed med naturen eller være en stemningsanviser, der skal få modtageren til at komme i en stemning, der minder om sidste gang, modtageren måske var i et landskab som det viste. Naturbillederne peger altså mod interesse for spiritualitet - på samme legitimerende måde som Buddha-billedet peger mod en interesse for buddhisme - da det er i den spirituelle kategori, man finder et udtalte ønske om harmoni med naturen. Derfor er det ikke nogen overraskelse, at hovedparten af dokumenterne her anvender naturbilleder. Men, at dokumenter i den a-religiøse kategori i så høj grad anvender billeder af naturen som billedmateriale, viser dels et - kategoriseringen uanset - fælles interessefelt, dels svagheden ved en generalisering som vilkår for en undersøgelse som denne.

Den manglende visualisering tolker jeg som et ønske om netop ikke at anvende underbevidst kommunikation, men at være præcis og informerende. Derfor peger denne gruppe generelt mod videnskabelighed og den a-religiøse kategori; men det er ligesom i tilfældet med anvendelsen af naturbilleder bemærkelsesværdigt, at en del af dokumenterne i den spirituelle kategori anvender denne type kommunikation uden samme type underbevidste visuelle referencemuligheder. Også inden for den visuelle del af dokumenternes kommunikation findes der referencer på tværs af kategorierne.

Den visuelle kommunikation kan på baggrund af ovenstående analyse siges både at være mere underbevidst kommunikerende og mere upræcis end den tekstuelle. Uanset om det skyldes det ene eller det andet, er det bemærkelsesværdigt, at der inden for de visuelle referencer blandt både spirituelle og a-religiøse udbydere i langt højere grad signaleres 'uden for kategori' end fx inden for de tekstuelle referencer.

\section{Mindfulness - buddhisme, spiritualitet eller a-religiøs teknik?}

Figur 5: 'Rent' eller 'blandet' udbud

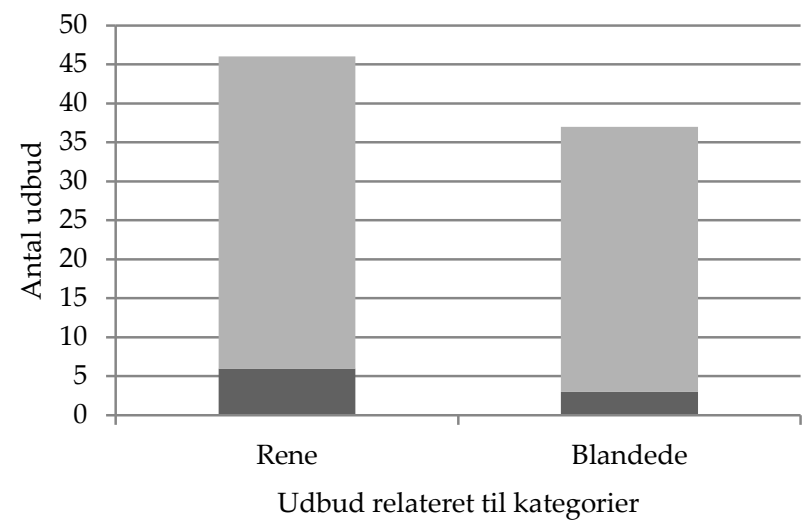

A-religiøs teknik

- Spiritualitet 
Ved at vende perspektivet fra de tre kategorier som grupperinger og i stedet følge den enkelte udbyder ses det, at 40 a-religiøse og 6 spirituelle udbydere signalerer 'rent' inden for sin kategori, altså udelukkende anvender autorisationer, tekst og visuelle referencer inden for enten den spirituelle eller den a-religiøse kategori.

Derfor vil den første del af svaret på artiklens spørgsmål om, hvorvidt mindfulness er en type buddhisme, spiritualitet eller a-religiøs teknik være, at mindfulness med belæg i denne analyses kriterier ikke udelukkende er buddhisme, men at buddhisme kan ses som en del af udbuddet. Til gengæld kan mindfulness være udelukkende spiritualitet (seks udbud), og det kan være udelukkende a-religiøs teknik (40 udbud). Det er dog ikke hele svaret, for det gælder kun for godt halvdelen af udbuddene.

\section{Mindfulness - buddhisme, spiritualitet og a-religiøs teknik?}

Der er nemlig en ikke ubetydelig del af samplet, 37 udbud, der blander kategorierne. Hvordan de blandes, ses her:

Figur 6: Blandet af hvilke?

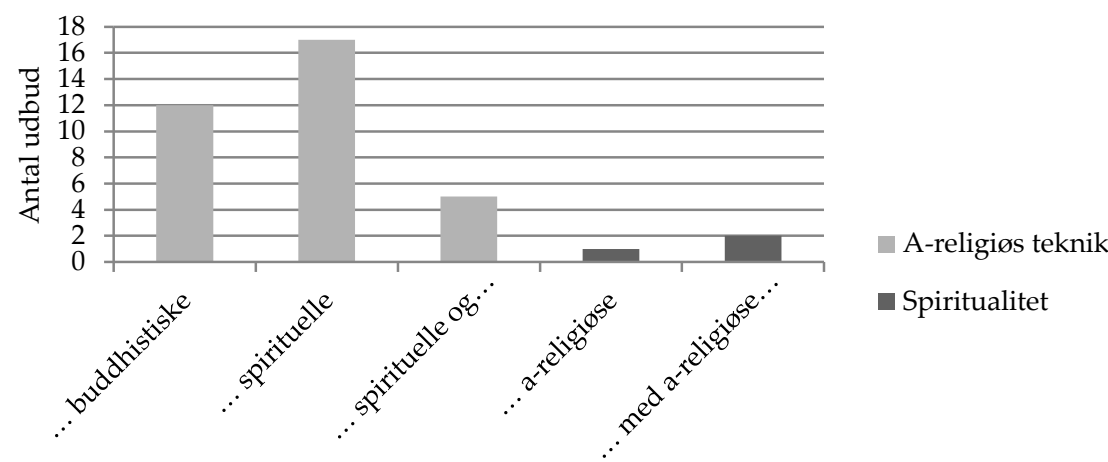

Kategorien er blandet med...

Således er der i den blandede del af den a-religiøse kategori tolv udbud, der også refererer til kriterier fra den buddhistiske kategori, 17 udbud, der refererer til kriterier fra den spirituelle og fem udbud, der refererer til kriterier fra både den buddhistiske og den spirituelle kategori. I den spirituelle kategori er der én, der refererer til kriterier fra den a-religiøse kategori og to, der refererer til kriterier fra både den a-religiøse og den buddhistiske kategori.

Der er altså en hel del af de a-religiøse, der anvender træk fra kategorier, som har et mere religiøst indhold, end de selv umiddelbart signalerer. Det endelig svar på, om mindfulness er en type buddhisme, spiritualitet eller a-religiøs teknik, er altså, at mindfulness, med belæg i denne analyses kriterier, ikke udelukkende er buddhisme; 
det kan være spiritualitet og det kan være a-religiøs-teknik; men mindfulness kan også være blandet af to eller tre af disse kategorier.

\section{Perspektiv}

Analyserne af mindfulness-udbyderes anvendelse af autorisation, tekst- og visuelle referencer gør det muligt på baggrund af empirien umiddelbart, men kun umiddelbart, at konkludere, at mindfulness ikke er en religion. Mindfulness udbydes nemlig slet ikke som buddhisme og kun sjældent som spiritualitet. Til gengæld udbydes det $\mathrm{i}$ altovervejende grad som en a-religiøs teknik. Dog iblandes der ofte spirituelle eller buddhistiske træk, der kunne efterlade tvivl om udbyderens udgangspunkt.

Måske det er denne tvivl, der kommer til udtryk i det større perspektiv: For med anvendelsen af Durkheims religionsdefinition og Hornborgs argument for sundhedsreligion som en ny og omfattende trosform kan mindfulness ses som en del af det ritual-korpus, der anvendes inden for denne religion. Mindfulness kan således ses som det a-religiøse menneskes måde at udøve religion på. Sundhedsreligion har nemlig hverken en guddom, en åndelig kraft eller en lære som helligdom, men har forbedringen, effektiviseringen og vedligeholdelsen af den fysiske krop som helligt mål. Hertil er Mindfulness Based Stress Reduction (MBSR) et effektivt redskab til at holde kroppen fri for stress, som blandt andet kan give udøveren mulighed for at være nærværende i en samtale og anvende bilkøen som en velkommen pause.

\section{LITTERATUR}

Barfred, Annette Munck

2011 En religionssociologisk analyse af udbredelse af mindfulness $i$ Danmark, Institut for Tværkulturelle Studier, Det Humanistiske Fakultet, Københavns Universitet.

Bauman, Zygmunt

2001 Frllesskab - En søgen efter tryghed i en usikker verden, Hans Reitzels Forlag, København.

Center for Samtidsreligion

2011 'Buddhistiske menigheder', http://teo.au.dk/csr/rel-aarbog11/god-tro/buddhistiske-adr-medl/ (set 13.12.2011)

Durkheim, Emile

1995 The Elementary Forms of Religious Life, The Free Press, New York [fransk 1912].

Harvey, Peter

1990 An Introduction to Buddhism, Cambridge University Press, UK.

Herbrechtsmeier, William

1993 'Buddhism and the Definition of Religion: One More Time', in: Journal for the Scientific Study of religion 32 (1), 1-18.

Hornborg, Anne-Christine

2010 'Marknadsföring av natur, hälsa och rituelt helande i det senmoderna Sverige', in: Den rituella människan: Flervetenskapliga perspektiv', Anne-Christine Hornborg, ed., Linköping University Electronic Press, Linköping, SE, 151-169. 
Hvas, Lotte

2012 'Sundhedisme er blevet den nye religion', Kristeligt Dagblad, 25.5.2012.

I Form

2011 'Udgivelser', http://bonnierpublications.com/publikationer/i-form (set 28.11.2011).

Kjeldsen, Jens E.

2006 'Billeders retorik' in: Marie Lund Klujeff \& Hanne Roer, eds., Retorikkens Aktualitet, Hans Reitzels Forlag, 161-196.

Krop-sind-ånd Helsemesse

2011 http://www.daninfo.dk/ss1794.sspx, (set 27.1.2011).

Perry, Michael

1992 Gods Within - A Critical Guide to the New Age, SPCK, UK.

Plank, Katarina

2011 Insikt och Närvaro - akademiska kontemplationer kring buddhism, meditation och mindfulness, Makadam, Sverige.

Szalavitz, Maia

2012 'Mind Reading: Jon Kabat-Zinn Talks About Bringing Mindfulness Meditation to Medicine', http://healthland.time.com/2012/01/11/mind-reading-jon-kabat-zinn-talks-about-bringingmindfulness-meditation-to-medicine (set 14.2.2012).

Taylor, Charles

1989 Sources of the Self. The Making of the Modern Identity, Cambridge University Press, Cambridge, UK.

2007 A Secular Age, The Belknap Press of Harvard University Press, Cambridge, UK.

Woodhead, Linda \& Paul Heelas

2000 Religion in Modern Times, Blackwell Publishers, Oxford, UK.

www.louisehay.com

2011 'About Hay House', http://www.louisehay.com/about-louise/hayhouse.php (set 29.12.2011).

www.umassmed.edu

2011 'Stress Reduction Program', http://umassmed.edu/Content.aspx?id=41268 (set 26.10.2011).

2012 'Mindfulness-Based Teen Program', http://www.umassmed.edu/Content.aspx?id=41310 (set d 18.3.2012).

Rikke Gottfredsen, cand.mag

Center for Undervisningsudvikling og Digitale Medier, Aarhus 